\title{
Private Sector Bank Services in Madurai
}

\section{Selvaraj $\mathbf{N}^{*}$}

Department of Commerce, Saraswathi Narayanan College, India

\begin{abstract}
Customers were simple persons and were happy with whatever services the banks had offered them. Over a period of time, with the competition and technological improvements, customers have become fully aware of their rights. Today banks are realizing that the quality of service constitutes the core of their business and it is a strategy with which they could highlight their superiority with their competitors. Gone are the days when customers had no option but to simply continue with the old strategy of one cap for all. Now-a-days, banks have come to understand that business can come from satisfied customers. A satisfied customer brings in more customers and he is the best advertisement for the bank. Though in the eighties transaction banking was the order of the day, relationship banking has regained its importance once again, with many banks throughout the world project forward this concept. Service quality is a judgmental issue relating to the different between an individual's expectation of a service and the actual service performed. The private sector banks should raise the quality of the financial services like the reasonability of the rate of interest paid for deposits, justification of the rate of interest charged on loans, fair commission on draft, affordability of the safety locker rent, less commission for funds transfer and reasonability of interest on housing loans.
\end{abstract}

Keyword: Funds; Customer service; Financial sector; Judgmental issue

\section{Introduction}

Banking being a service industry, a lot depends on efficient and prompt customer service. Prompt and efficient service with a smile will develop good public relations, reduce complaints and increase business. In the field of banking, it is very difficult to define the term "customer". Different views have been expressed at different times. In the early periods, a man who held some sort of an account with the bank was considered to be a customer. ${ }^{1}$

In the past, customers were simple persons and were happy with whatever services the banks had offered them. Over a period of time, with the competition and technological improvements, customers have become fully aware of their rights. Now-a-days customer service aims to usher in customer satisfaction and their delight and finally they look forward to customer ecstasy. ${ }^{2}$ Various alternatives are available to enlightened customers and they choose only those banks that they consider suit best to their needs. Customers have identified the quality issue as one of their primary concerns. Today banks are realizing that the quality of service constitutes the core of their business and it is a strategy with which they could highlight their superiority with their competitors. Gone are the days when customers had no option but to simply continue with the old strategy of one cap for all. A customer is the most important person who visits the premises of a bank. He is not dependent on the bank; rather the bank is dependent on him. He should not be considered as a rude interruption in work, rather he is the purpose of the work. But for customers, banks may not have any business or work. He is therefore, not an outsider but a part of the bank and its business. Banks are certainly not doing him any favour by serving him; he is doing a favour to the bank by giving it an opportunity to do so. These are the quotes of the Father of the Nation, Gandhi.

During the 1950s and 1960s, the perception of the banks was to serve the customers rather than to satisfy the customers. Service to customers to their satisfaction was absent during that period. After the nationalization of banks in 1969, they were more akin to customer

1 Gordon \& Natarajan, "Banking Theory, Law and Practice", Himalaya Publishing House, Bombay, 2005, p.3.

2 Pathasarathi B.R, "Customer Service in Banks and Its Importance", Professional Banker, November, 2005, p.17. orientation rather than profit orientation. After the financial sector reforms in 1990, the banks have got the onus to gratify the customers to retain them in their fold [1].

Now-a-days, banks have come to understand that business can come from satisfied customers. And also, there is a strong notion that there is need for a transition from the product centric to the customer centric approach. To understand the customer base, there is need to realize the relationship a customer has with the banks and financial services strategy. As such, it becomes imperative for the banks to integrate the products and bank personnel to provide better customer service with an assurance for easier access and transparency in all transactions. It has made it necessary to have a unified customer view that will help both the bank and the customers. In the context of this changing environment, with a view to win the hearts and wallets of customers, banks have been adopting modern marketing knowledge to their advantage.

A satisfied customer brings in more customers and he is the best advertisement for the bank. Though in the eighties transaction banking was the order of the day, relationship banking has regained its importance once again, with many banks throughout the world project forward this concept. A successful bank of the future will be one that excels in a satisfactory customer service, provides a range of services, products and does a continuous exercise in improving its potential to serve better. $^{3}$

Service quality is a judgmental issue relating to the different 3 Shetty J.V., "Customer Service in Banks", Vinimaya, July - September, 2008 pp.5-10.

*Corresponding author: Selvaraj N, Department of Commerce, Saraswathi Narayanan College, India, Tel: +9843727975; E-mail: selvaraj_narayanan@yahoo.com

Received January 05, 2016; Accepted February 12, 2016; Published February 16, 2016

Citation: Selvaraj N (2016) Private Sector Bank Services in Madurai. J Glob Econ 4: 179. doi:10.4172/2375-4389.1000179

Copyright: @ 2016 Selvaraj N . This is an open-access article distributed under the terms of the Creative Commons Attribution License, which permits unrestricted use, distribution, and reproduction in any medium, provided the original author and source are credited. 
between an individual's expectation of a service and the actual service performed. Many definitions are presented to the concept of service quality. Phrases such as "meeting customers wants, when they want them at an acceptable cost" are well-known explanations of the meaning of quality.

\section{Methodology}

The present study is based on both primary and secondary sources. The primary data was collected from the customers of commercial banks by sample survey through structural interview schedule. The secondary data were collected from books, journals, newspapers, periodicals, reports, Internet and the like.

\section{Period of the study}

The study covers a period of ten years from 2005-2006 to 20142015.

\section{Sample design}

The study entitled customer perception to the services of commercial banks in Madurai city is carried out in the Temple city which is the second largest one in Tamil Nadu. Twenty four public sector banks and fifteen private sector banks function in Madurai district. On the whole twenty branches were selected from public and private sector banks respectively.

\section{Field work and collection of data}

Field work for this study was carried out by the researcher himself. The researcher had used the interview schedule for collecting data from bank customers. After collecting the information through the interview schedule the data were verified and edited. The survey was conducted during the period from January 2015 to June 2015.

\section{Frame work of analysis}

After the collection of data, the filled in interview schedules were edited. A master table was prepared to sum up all the information contained in the interview schedule. The classification of tables had been made for analysis. While analyzing the data the following tools were applied:

\section{Coefficient of Variance}

Weighted Scoring Technique

\section{Factors Measuring Customer Service Quality}

To measure the opinion of the customers on the quality of services various factors which are germane to them were identified fewer than ten broad dimensions. A five point scale was constructed for each of these parameters. The parameters identified are given in Table 1.

In the present section the customers' service quality gap measured for each of the service items under the ten broad dimensions of private sector banks are discussed.

\section{Service quality gap of private sector banks in tangibility di- mension}

The perceived and desired levels of average scores and the resultant service quality gap that arises in the case of tangibility dimension is presented vide (Table 2).

Table 2 tells us that the highest average score had gone to the individual variable on the "upholstery and convenience (3.79)". The next score 3.71 had been given to the variable on "availability of bank

\begin{tabular}{|c|c|c|}
\hline I & Tangibility & $\begin{array}{l}\text { 1.Parking space on the bank premises. } \\
\text { 2.Adequacy of space and layout of counters } \\
\text { 3.Availability of bank Stationery } \\
\text { 4.Sign boards indicating of timings at appropriate } \\
\text { counters. } \\
\text { 5.Upholstery and convenience. } \\
\text { 6.Bank staff adequacy. }\end{array}$ \\
\hline II & Reliability & $\begin{array}{l}\text { 1. Uniform level of service at all times. } \\
\text { 2.Rendering promised service. } \\
\text { 3. Clarity of entries in the pass book. } \\
\text { 4.Safe bank transactions. } \\
\text { 5.Prompt services. } \\
\text { 6.Appropriateness and updating of the account } \\
\text { statements. }\end{array}$ \\
\hline III & Responsiveness & $\begin{array}{l}\text { 1.Interest and willingness of the bank staff to clarify } \\
\text { doubts and queries. } \\
\text { 2.Emergency and seriousness response. } \\
\text { 3.Attitude of the bank staff if a scheduled appointment is } \\
\text { not kept up by the customer. } \\
\text { 4.Grievances care and the follow up actions. } \\
\text { 5.Rendering of services on approach. } \\
\text { 6.Service without sulking. }\end{array}$ \\
\hline IV & Assurance & $\begin{array}{l}\text { 1.Skill of the bank staff to use computers and other } \\
\text { modern technical devices. } \\
\text { 2.Staff attitude and courtesy. } \\
\text { 3. Conveying of information in customer known } \\
\text { languages. } \\
\text { 4.Instilling customer confidence. } \\
\text { 5.Continuous service during business hours. } \\
\text { 6.Staff response to grievances. }\end{array}$ \\
\hline V & Accessibility & $\begin{array}{l}\text { 1.Staff accessibility and contact. } \\
\text { 2.Branch manager and higher officials' accessibility. } \\
\text { 3.Staff accessibility over telephone. } \\
\text { 4.Service counters accessibility. } \\
\text { 5.Proximity of the bank location. } \\
\text { 6.Bank branch adequacy in other areas. }\end{array}$ \\
\hline VI & Empathy & $\begin{array}{l}\text { 1. Understanding the specific needs of customers. } \\
\text { 2.Individual attention to the customers. } \\
\text { 3.Convenient bank working hours. } \\
\text { 4.Customer discrimination. } \\
\text { 5.Bank's efforts to know the customer and his needs. } \\
\text { 6.Staff's polite approach with customers. }\end{array}$ \\
\hline VII & Financial & $\begin{array}{l}\text { 1.Reasonability of the rate of interest paid. } \\
\text { 2.Justification of the rate of interest charged. } \\
\text { 3.Fair draft commission. } \\
\text { 4.Affordability of the safety locker rent. } \\
\text { 5.Less commission for funds transfer. } \\
\text { 6. Reasonability of housing loan rate of interest. }\end{array}$ \\
\hline VIII & Technology & $\begin{array}{l}\text { 1.Application of computer technology to provide service. } \\
\text { 2.ATMs. } \\
\text { 3.E-banking. } \\
\text { 4.Core banking. } \\
\text { 5.Mobile banking. } \\
\text { 6. Online banking security. }\end{array}$ \\
\hline IX & Agency & $\begin{array}{l}\text { 1.Payments and collection of subscriptions, dividends, } \\
\text { salaries, pensions, etc., } \\
\text { 2.Purchase and sales of securities. } \\
\text { 3.Executor, administrator and trustee. } \\
\text { 4.Attorney. } \\
\text { 5.Cash exchanger. } \\
\text { 6.Financial planners, investment advisors and brokers. }\end{array}$ \\
\hline$x$ & Miscellaneous & $\begin{array}{l}\text { 1.Valuables safe custody. } \\
\text { 2.Letter of credit. } \\
\text { 3.Travellar's Cheques. } \\
\text { 4.Foreign exchange business. } \\
\text { 5.Leasing finance. } \\
\text { 6.Factoring. }\end{array}$ \\
\hline
\end{tabular}

Table 1: Parameters to measure quality of services 


\begin{tabular}{|c|c|c|c|c|c|c|}
\hline \multirow{2}{*}{$\begin{array}{l}\text { Description of Factor } \\
\text { on Tangibility }\end{array}$} & \multicolumn{2}{|c|}{ Perceived Level } & \multicolumn{2}{|c|}{ Desired Level } & \multicolumn{2}{|c|}{ Gap } \\
\hline & Score & CV (\%) & Score & CV (\%) & Score & $\begin{array}{l}\text { CV } \\
(\%)\end{array}$ \\
\hline $\begin{array}{l}\text { Parking space in the bank } \\
\text { premises }\end{array}$ & $\begin{array}{r}2.28 \\
(571)\end{array}$ & 51.62 & $\begin{array}{r}4.62 \\
(1155)\end{array}$ & 13.36 & $\begin{array}{r}-2.34 \\
(-584)\end{array}$ & 46.5 \\
\hline $\begin{array}{l}\text { Adequacy of space and } \\
\text { layout of counters }\end{array}$ & $\begin{array}{r}3.26 \\
(815)\end{array}$ & 33.68 & $\begin{array}{r}4.71 \\
(1177)\end{array}$ & 12.46 & $\begin{array}{r}-1.45 \\
(-362)\end{array}$ & 71.5 \\
\hline $\begin{array}{l}\text { Availability of bank } \\
\text { stationery }\end{array}$ & $\begin{array}{r}3.71 \\
(927)\end{array}$ & 34.66 & $\begin{array}{r}4.77 \\
(1193)\end{array}$ & 15.72 & $\begin{array}{r}-1.06 \\
(-266)\end{array}$ & 97. \\
\hline $\begin{array}{l}\text { Sign boards indicating } \\
\text { of timings at appropriate } \\
\text { counters }\end{array}$ & $\begin{array}{r}2.95 \\
(738)\end{array}$ & 49.70 & $\begin{array}{r}4.70 \\
(1175)\end{array}$ & 16.43 & $\begin{array}{r}-1.75 \\
(-437)\end{array}$ & 80.7 \\
\hline $\begin{array}{l}\text { Upholstery and } \\
\text { convenience }\end{array}$ & $\begin{array}{r}3.79 \\
(947)\end{array}$ & 31.08 & $\begin{array}{r}4.86 \\
(1216)\end{array}$ & 10.21 & $\begin{array}{r}-1.08 \\
(-269)\end{array}$ & 99.1 \\
\hline Bank staff adequacy & $\begin{array}{r}3.54 \\
(884)\end{array}$ & 34.44 & $\begin{array}{r}4.86 \\
(1215)\end{array}$ & 10.27 & $\begin{array}{r}-1.32 \\
(-331)\end{array}$ & 78.4 \\
\hline
\end{tabular}

Source: Computed from primary data

Note: Figures in parentheses indicate the individual factor score

Table 2: Service quality gap of private sector banks in tangibility dimension

stationery". The third highest score was accorded to the factor on "bank staff adequacy". This variable had recorded an average score of 3.54 . The variable which had secured the least mean score of 2.28 was the "parking space in the bank premises". The lowest dispersion was being taken up by the variable on "upholstery and convenience". The value of the variation was $31.08 \%$.

It can be seen from table that in the case of the desired level of satisfaction, the average scores were found to be highest for the variables on the "upholstery and convenience" and "bank staff adequacy" with an equal average score of 4.86 . The next highest score was recorded by the factor on "availability of bank stationery". This variable had recorded a mean score of 4.77. The factor that had taken the least average score was the individual variable on "parking space in the bank premises (4.62)". The coefficient of variations calculated for these individual variables on tangibility, the variable on "upholstery and convenience" had the lowest dispersion of $10.21 \%$.

It is seen wide table, that the service quality gap in the case of tangibility dimension indicates the least negative value in the case of "availability of bank stationery (-1.06)". This was followed by the factor on "upholstery and convenience (-1.08)". The next lowest gap was found in the case of "bank staff adequacy $(-1.32)$ ". The average score was found to be the highest in the case of the variable on the "parking space in the bank premises (-2.34)". The lowest coefficient of variation was calculated in the case of the variable on "parking space in the bank premises (46.58\%)".

From the analysis it can be seen that the factor on "parking space in the bank premises" had recorded the highest service quality gap and the same variable had registered the lowest variation of $46.58 \%$ [2].

\section{Service quality gap of private sector banks in reliability di- mension}

Table 3 examines the perceived and desired levels of average scores and the resultant service quality gap that arises in the case of reliability dimension.

Table 3 on the customers' perceived level of service quality, among the various factors of reliability dimension, the highest average score was being taken up by the variable on "safe bank transactions (3.92)". The next highest score had gone to the factor on "prompt services (3.79)". The third highest score went to the variable on "appropriate and updating of the account statements (3.36)". The factor that has taken the least average score was the individual variable on "clarity of entries in the pass book (3.02)". The lowest coefficient of variation was recorded by the variable on the "safe bank transactions (24.29\%)".

An analysis on the customers' desired level of satisfaction on the reliability dimension indicates that the mean score was the highest in the case of "safe bank transactions (4.99)". The second highest score was recorded in the case of "clarity of entries in the pass book (4.93)". While the average score of the variable on "rendering promised service" was 4.89 , the score on appropriate and updating of the account statements constituted 4.86 and the factor on prompt services had recorded the value of 4.81. The factor on "uniform level of service at all times (4.72)" had recorded the least average score. The lowest coefficient of variation was being recorded by the factor on "safe bank transactions (2.18\%)".

A study on the service quality gap in the case of the dimension on reliability indicates that the factor on "prompt services (-1.02)" recorded the least. The next lowest gap was in the case of "safe bank transactions $(-1.06)$ ". The third least value was found in the factor on "appropriate and updating of the account statements" with -1.51. The next lowest gap was recorded in the case of the factor on the uniform level of service at all times (1.63). The highest service quality gap was in the case of the variable on the "clarity of entries in the pass book $(-1.91)$ ". The lowest coefficient of variation was in the case of "clarity of entries in the pass book (48.85\%)".

From the analysis, it was seen that the highest service quality gap was seen in the case of the variable on "clarity of entries in the pass book $(-1.91)$ ", while the same variable had scored the least coefficient of variation of $48.85 \%$.

\section{Service quality gap of private sector banks in responsiveness dimension}

The perceived and desired levels of resultant service quality gap of private sector banks in the case of the responsiveness dimension is presented vide (Table 4).

Among the various factors of responsiveness dimension, the highest score was given to the factor on "rendering of services when approached (3.44)". The next highest value was obtained by the factor on "service without sulking (3.18)". This was followed by the factor on "grievances care and the follow up actions". This variable had got a value of 3.13. The least value of 2.63 had gone to the factor on "attitude of the bank staff if a scheduled appointment is not kept up by the customer". The least coefficient of variation calculated for the perceived level of service quality had gone to "rendering of services when approached (26.80\%)".

\begin{tabular}{|l|l|l|l|l|l|l|}
\hline $\begin{array}{l}\text { Description of Factor } \\
\text { on Reliability }\end{array}$ & \multicolumn{3}{|l|}{ Perceived Level } & Desired Level & Gap & \\
\cline { 2 - 7 } & Score & CV (\%) & Score & CV (\%) & Score & CV (\%) \\
\hline $\begin{array}{l}\text { Uniform level of service at } \\
\text { all times. }\end{array}$ & $\begin{array}{l}3.09 \\
(773)\end{array}$ & 38.64 & $\begin{array}{l}4.72 \\
(1181)\end{array}$ & 12.31 & $\begin{array}{l}-1.63 \\
(-408)\end{array}$ & 65.77 \\
\hline $\begin{array}{l}\text { Rendering promised } \\
\text { service }\end{array}$ & $\begin{array}{l}3.10 \\
(776)\end{array}$ & 36.07 & $\begin{array}{l}4.89 \\
(1223)\end{array}$ & 6.63 & $\begin{array}{l}-1.79 \\
(-447)\end{array}$ & 58.16 \\
\hline $\begin{array}{l}\text { Clarity of entries in the } \\
\text { pass book }\end{array}$ & $\begin{array}{l}3.02 \\
(755)\end{array}$ & 34.04 & $\begin{array}{l}4.93 \\
(1232)\end{array}$ & 5.25 & -1.91 & 48.85 \\
\hline Safe bank transactions & $\begin{array}{l}3.92 \\
(981)\end{array}$ & 24.29 & $\begin{array}{l}4.99 \\
(1247)\end{array}$ & 2.18 & -1.06 & 90.09 \\
\hline Prompt services & $\begin{array}{l}3.79 \\
(947)\end{array}$ & 30.00 & $\begin{array}{l}4.81 \\
(1203)\end{array}$ & 8.13 & $\begin{array}{l}-1.02 \\
(-256)\end{array}$ & 110.00 \\
\hline $\begin{array}{l}\text { Appropriate and updating } \\
\text { of the account statements }\end{array}$ & $\begin{array}{l}3.36 \\
(839)\end{array}$ & 42.65 & $\begin{array}{l}4.86 \\
(1216)\end{array}$ & 10.39 & -1.51 & 86.29 \\
\hline
\end{tabular}

Source: Computed from primary data

Note: Figures in parentheses indicate the individual factor score

Table 3: Service quality gap of private sector banks in reliability dimension 


\begin{tabular}{|l|l|l|l|l|l|l|}
\hline $\begin{array}{l}\text { Description of Factor } \\
\text { on Responsiveness }\end{array}$ & \multicolumn{2}{l}{ Perceived Level } & Desired Level & \multicolumn{2}{l|}{ Gap } \\
\cline { 2 - 8 } & Score & CV (\%) & Score & CV (\%) & Score & $\begin{array}{l}\text { CV } \\
\text { (\%) }\end{array}$ \\
\hline $\begin{array}{l}\text { Interest and willingness } \\
\text { of the bank staff to clarify } \\
\text { doubts and queries }\end{array}$ & $\begin{array}{l}2.91 \\
(728)\end{array}$ & 34.57 & $\begin{array}{l}4.83 \\
(1208)\end{array}$ & 10.74 & $\begin{array}{l}-1.92 \\
(-480)\end{array}$ & 46.98 \\
\hline $\begin{array}{l}\text { Emergency and reflex } \\
\text { response }\end{array}$ & $\begin{array}{l}3.01 \\
(753)\end{array}$ & 37.94 & $\begin{array}{l}4.80 \\
(1199)\end{array}$ & 15.44 & -1.78 & 58.09 \\
\hline $\begin{array}{l}\text { Attitude of the bank staff if } \\
\text { a scheduled appointment } \\
\text { is not kept up by the } \\
\text { customer }\end{array}$ & $\begin{array}{l}2.63 \\
(658)\end{array}$ & 35.59 & $\begin{array}{l}4.63 \\
(1158)\end{array}$ & 15.25 & $\begin{array}{l}-2.00 \\
(-500)\end{array}$ & 40.80 \\
\hline $\begin{array}{l}\text { Grievances care and the } \\
\text { follow up actions }\end{array}$ & $\begin{array}{l}3.13 \\
(782)\end{array}$ & 31.21 & $\begin{array}{l}4.80 \\
(1201)\end{array}$ & 8.69 & $\begin{array}{l}-1.68 \\
(-419)\end{array}$ & 57.02 \\
\hline $\begin{array}{l}\text { Rendering of services } \\
\text { when approached }\end{array}$ & $\begin{array}{l}3.44 \\
(861)\end{array}$ & 26.80 & $\begin{array}{l}4.96 \\
(1239)\end{array}$ & 4.52 & $\begin{array}{l}-1.51 \\
(-378)\end{array}$ & 63.44 \\
\hline Service without sulking & $\begin{array}{l}3.18 \\
(796)\end{array}$ & 28.15 & $\begin{array}{l}4.92 \\
(1229)\end{array}$ & 6.46 & $\begin{array}{l}-1.73 \\
(-433)\end{array}$ & 47.63 \\
\hline
\end{tabular}

Source: Computed from primary data

Note: Figures in parentheses indicate the individual factor score

Table 4: Service quality gap of private sector banks in responsiveness dimension

In table, the average score of the dimension on the responsiveness of the desired level of service quality is discussed. It is seen that the highest score was given to the factor "rending of service when approached (4.96)". The next highest score was recorded by the category on the "service without sulking (4.92)". The third highest score went to the variable on "interest and willingness of the bank staff to clarify doubts and queries". It had scored a value of 4.83. The factors on "grievances care and the follow up actions" and "emergency and reflex response" had an equal score of 4.80 each. The factor on "attitude of the bank staff if a scheduled appointment is not kept up by the customer" secured a score of 4.63. This variable constituted the least score. The lowest dispersion was recorded in the case of the variable on "rendering of services when approached (4.52\%)".

Among the various variables considered under the dimension on responsiveness, the variable on the "attitude of the bank staff if a scheduled appointment is not kept up by the customer" constituted the highest gap of -2.00 . The next higher gap was recorded in the case of the variable on "interest and willingness of the bank staff to clarify doubts and queries (-1.92)". The variable on "emergency and reflex response (-1.78)" came next. The least average score of -1.51 was being recorded in the case of the factor on "rendering of services when approached". The lowest coefficient of variation was recorded in the case of the factor on "attitude of the bank staff if a scheduled appointment is not kept up by the customer (40.80\%)".

This analysis points out that the factor on "attitude of the bank staff if a scheduled appointment is not kept up by the customer" formed the highest service quality gap indicating that it had the highest gap between the perceived (2.63) and the desired (4.63) levels [3].

\section{Service quality gap of private sector banks in assurance di- mension}

The perceived and desired levels of average scores and the resultant service quality gap that arises in the case of assurance dimension are discussed vide (Table 5).

The average score of the individual variable on assurance dimension indicates that the highest score was taken up by the individual factor on "staff's skill in computer technology". This variable had scored the highest value of 3.60. The next score was given to the variable on the "staff attitude and courtesy (3.48)". The third highest average score went to the variable on "instilling customer confidence (3.46)". The lowest value of 3.19 had been accorded to the variable on "continuous service during business hours". In terms of the measure of the dispersion, the lowest value of coefficient of variation of $23.47 \%$ was given to the variable on "instilling customer confidence".

Regarding the desired level, the average score on "staff's skill in computer technology" constituted the highest with 4.93 . This variable had recorded the lowest coefficient of variation $(5.11 \%)$. The second highest mean score was registered by the three factors namely, "staff attitude and courtesy", "conveying of information in customer known languages" and "staff response to grievances (4.92 each)". In terms of the mean score, the variable on "instilling customer confidence" recorded a mean value of 4.85 and this was being followed by the factor on "continuous service during business hours" which constituted a least score of 4.80 .

It is seen from the table that out of the six individual factors of service quality gap, the factor on "continuous service during business hours" constituted the highest score with -1.60 . The next highest gap was found in the case of variable on "conveying information in customers known languages (-1.59)". The third highest score of -1.56 was recorded in the case of the factor on "staff response to grievances". The lowest gap was found in the variable on "staff's skill in computer technology (-1.33)". The factor on "instilling customer confidence" had registered the lowest dispersion of $51.14 \%$.

From the analysis it can be seen that the factor on "continuous service during business hours (-1.60)" had recorded the highest score of service quality gap and in terms of coefficient of variation it had registered the highest dispersion of $69.25 \%$.

\section{Service quality gap of private sector banks in accessibility di- mension}

The perceived and desired levels of average scores and the resultant service quality gap that arises in the case of accessibility dimension is presented vide (Table 6).

The data on the dimension on accessibility, the highest score of 3.58 was registered by the variable on the "proximity of the bank location". The next highest mean score was given to the two variables namely, "service counters accessibility" and "staff accessibility and contact (3.31 each)". The factors: staff accessibility over telephone (2.90), branch manager and higher officials' accessibility (2.71) and bank branch

\begin{tabular}{|c|c|c|c|c|c|c|}
\hline \multirow{2}{*}{$\begin{array}{l}\text { Description of Factor } \\
\text { on Assurance }\end{array}$} & \multicolumn{2}{|c|}{ Perceived Level } & \multicolumn{2}{|c|}{ Desired Level } & \multicolumn{2}{|l|}{ Gap } \\
\hline & Score & CV (\%) & Score & CV (\%) & Score & $\begin{array}{l}\text { CV } \\
(\%)\end{array}$ \\
\hline $\begin{array}{l}\text { Staff's skill in computer } \\
\text { technology }\end{array}$ & $\begin{array}{l}3.60 \\
(900)\end{array}$ & 24.28 & $\begin{array}{l}4.93 \\
(1233)\end{array}$ & 5.11 & $\begin{array}{l}-1.33 \\
(-333)\end{array}$ & 58.65 \\
\hline Staff attitude and courtesy & $\begin{array}{l}3.48 \\
(871)\end{array}$ & 25.00 & $\begin{array}{l}4.92 \\
(1231)\end{array}$ & 5.69 & $\begin{array}{l}-1.44 \\
(-360)\end{array}$ & 59.65 \\
\hline $\begin{array}{l}\text { Conveying of information } \\
\text { in customer known } \\
\text { languages }\end{array}$ & $\begin{array}{l}3.34 \\
(834)\end{array}$ & 30.93 & $\begin{array}{l}4.92 \\
(1231)\end{array}$ & 5.69 & $\begin{array}{l}-1.59 \\
(-397)\end{array}$ & 65.54 \\
\hline $\begin{array}{l}\text { Instilling customer } \\
\text { confidence }\end{array}$ & $\begin{array}{l}3.46 \\
(864)\end{array}$ & 23.47 & $\begin{array}{l}4.85 \\
(1213)\end{array}$ & 10.74 & $\begin{array}{l}-1.40 \\
(-349)\end{array}$ & 51.14 \\
\hline $\begin{array}{l}\text { Continuous service during } \\
\text { business hours }\end{array}$ & $\begin{array}{l}3.19 \\
(798)\end{array}$ & 39.06 & $\begin{array}{l}4.80 \\
(1199)\end{array}$ & 15.77 & $\begin{array}{l}-1.60 \\
(-401)\end{array}$ & 69.25 \\
\hline $\begin{array}{l}\text { Staff response to } \\
\text { grievances. }\end{array}$ & $\begin{array}{l}3.36 \\
(840)\end{array}$ & 32.32 & $\begin{array}{l}4.92 \\
(1230)\end{array}$ & 6.10 & $\begin{array}{l}-1.56 \\
(-390)\end{array}$ & 60.45 \\
\hline
\end{tabular}

Source: Computed from primary data

Note: Figures in parentheses indicate the individual factor score

Table 5: Service quality gap of private sector banks in assurance dimension 


\begin{tabular}{|l|l|l|l|l|l|l|l|}
\hline $\begin{array}{l}\text { Description of Factor } \\
\text { on Accessibility }\end{array}$ & \multicolumn{2}{|l|}{ Perceived Level } & \multicolumn{2}{l|}{ Desired Level } & Gap & \\
\cline { 2 - 7 } & Score & CV (\%) & Score & CV (\%) & Score & $\begin{array}{l}\text { CV } \\
(\%)\end{array}$ \\
\hline $\begin{array}{l}\text { Staff accessibility and } \\
\text { contact }\end{array}$ & 3.31 & 31.66 & $\begin{array}{l}4.79 \\
(1197)\end{array}$ & 15.76 & $\begin{array}{l}-1.48 \\
(-370)\end{array}$ & 58.18 \\
\hline $\begin{array}{l}\text { Branch manager } \\
\text { and higher officials' } \\
\text { accessibility }\end{array}$ & $\begin{array}{l}2.71 \\
(678)\end{array}$ & 49.67 & $\begin{array}{l}4.83 \\
(1207)\end{array}$ & 10.95 & $\begin{array}{l}-2.12 \\
(-529)\end{array}$ & 60.33 \\
\hline $\begin{array}{l}\text { Staff accessibility over } \\
\text { telephone }\end{array}$ & $\begin{array}{l}2.90 \\
(725)\end{array}$ & 35.28 & $\begin{array}{l}4.76 \\
(1189)\end{array}$ & 16.30 & $\begin{array}{l}-1.86 \\
(-464)\end{array}$ & 47.58 \\
\hline $\begin{array}{l}\text { Service counters } \\
\text { accessibility }\end{array}$ & $\begin{array}{l}3.31 \\
(828)\end{array}$ & 25.53 & $\begin{array}{l}4.89 \\
(1223)\end{array}$ & 6.63 & -1.58 & $(-395)$ & 51.20 \\
\hline $\begin{array}{l}\text { Proximity of the bank } \\
\text { location }\end{array}$ & $\begin{array}{l}3.58 \\
(895)\end{array}$ & 27.49 & $\begin{array}{l}4.90 \\
(1224)\end{array}$ & 6.51 & $\begin{array}{l}-1.32 \\
(-329)\end{array}$ & 73.79 \\
\hline $\begin{array}{l}\text { Bank branch adequacy in } \\
\text { other areas }\end{array}$ & $\begin{array}{l}2.47 \\
(617)\end{array}$ & 39.27 & $\begin{array}{l}4.76 \\
(1191)\end{array}$ & 15.92 & $\begin{array}{l}-2.30 \\
(-574)\end{array}$ & 41.26 \\
\hline
\end{tabular}

Source: Computed from primary data

Note: Figures in parentheses indicate the individual factor score

Table 6: Service quality gap of private sector banks in accessibility dimension

adequacy in other areas constituted the least value of 2.47. The lowest coefficient of variation was given to "service counters accessibility (25.53\%)".

As far as the desired level of service quality is concerned, the factor on "proximity of the bank location (4.90)" had the highest average score. Next came the factors on "service counters accessibility (4.89), branch manager and higher officials' accessibility (4.83) and staff accessibility and contact (4.79)". The lowest average score went to the two variables, "staff accessibility over telephone" and "bank branch adequacy in other areas" which constituted 4.76 each. The lowest coefficient of variation was seen in the case of "proximity of the bank location (6.51\%)".

Among the six broad categories of individual factor that determines the dimension on accessibility the factor on "bank branch adequacy in other areas $(-2.30)$ " had the highest gap. The next highest value was found in the case of the variable on "branch manager and higher officials' accessibility". This variable had recorded the average score of -2.12. The third highest score went to the variable on "staff accessibility over telephone (-1.86)". The lowest gap was found in the factor on "proximity of the bank location" with -1.32 . The lowest coefficient of variation was recorded in the case of "bank branch adequacy in other areas $(41.26 \%)$.

From the analysis, it can be surmised that the factor on "bank branch adequacy in other areas $(-2.30)$ " had recorded the highest score and in terms of coefficient of variation it had registered the least dispersion of $41.26 \%$.

\section{Service quality gap of private sector banks in empathy dimen- sion}

Table 7 explains the perceived and desired levels of average scores and the resultant service quality gap that arises in the case of empathy dimension in the operation of the private sector banks.

The average score on the empathy dimension indicates that in the case of the perceived level of satisfaction of the customers, the highest average score was obtained by the individual factor on the "staff's polite approach with customers (3.43)". This was followed by the variable on "individual attention to the customers". This variable had a mean score of 3.32. The next highest score was obtained by the factor on the "understanding the specific needs of customers". This variable had recorded an average score of 3.11. The variable which had secured the least mean score of 2.75 was "customer discrimination".
The lowest coefficient of variation was seen in the variable on "staff's polite approach with customers (28.92\%)".

It is seen from the table that in the case of the desired level of satisfaction, the average score was found to be the highest in the variable on the "individual attention to the customers (4.93)". The next highest score was recorded by the factor on "convenient banking hours". This variable had recorded a mean score of 4.87 . The third highest score was recorded by the variable on "customer discrimination (4.86)". The factor that had taken the least average score is the individual variable on "understanding the specific needs of customers (4.73)". The variable on "individual attention to the customers" constituted the lower dispersion of $5.25 \%$.

The service quality gap in the case of empathy dimension indicates that it was the least negative value in the case of "staff's polite approach with customers (-1.37)". This was followed by the factor on "individual attention to the customers $(-1.61)$ ". The third lowest gap was found in the factor "understanding the specific needs of customers (-1.62)". The variable on "customer discrimination (-2.12)" constituted the highest score in terms of service quality gap and the lowest variance was calculated in the case of the same variable with $43.49 \%$.

From the analysis it can be seen that the factor on "customer discrimination" had recorded the highest service quality gap.

\section{Service quality gap of private sector banks in financial dimen- sion}

The perceived and desired levels of average scores and the resultant service quality gap that arises in the case of financial dimension are shown vide (Table 8).

Table 8 presents the customers' perceived level of service quality among the various factors of financial dimension. The highest average score was taken up by the variable on "justification of the rate of interest charged (2.97)". The next highest score went to the factor on "reasonability of the rate of interest paid (2.86)". The factor on "fair draft commission" constituted the third highest score of 2.78 . The lowest score was recorded in the case of "less commission for funds transfer (2.28)". The lowest coefficient of variation was seen in the variable on reasonability of the rate of interest paid (32.06\%).

The table indicates that the mean score was the highest in the case of "justification of the rate of interest charged (4.56)". The next highest score was obtained by two factors namely, "reasonability of the rate of

\begin{tabular}{|l|c|c|c|c|c|c|}
\hline \multicolumn{1}{|c|}{$\begin{array}{c}\text { Description of Factor } \\
\text { on Empathy }\end{array}$} & \multicolumn{2}{|c|}{ Perceived Level } & \multicolumn{2}{|c|}{ Desired Level } & \multicolumn{2}{|c|}{ Gap } \\
\cline { 2 - 7 } & Score & CV (\%) & Score & CV (\%) & Score & $\begin{array}{c}\text { CV } \\
\text { (\%) }\end{array}$ \\
\hline $\begin{array}{l}\text { Understanding the specific } \\
\text { needs of customers }\end{array}$ & $\begin{array}{c}3.11 \\
(777)\end{array}$ & 30.77 & $\begin{array}{c}4.73 \\
(1182)\end{array}$ & 16.15 & $\begin{array}{c}-1.62 \\
(-405)\end{array}$ & 52.90 \\
\hline $\begin{array}{l}\text { Individual attention to the } \\
\text { customers }\end{array}$ & $\begin{array}{c}3.32 \\
(830)\end{array}$ & 37.80 & $\begin{array}{c}4.93 \\
(1232)\end{array}$ & 5.25 & $\begin{array}{c}-1.61 \\
(-402)\end{array}$ & 75.28 \\
\hline Convenient banking hours & $\begin{array}{c}3.01 \\
(752)\end{array}$ & 35.35 & $\begin{array}{c}4.87 \\
(1218)\end{array}$ & 10.06 & $\begin{array}{c}-1.86 \\
(-466)\end{array}$ & 49.79 \\
\hline Customer discrimination & $\begin{array}{c}2.75 \\
(687)\end{array}$ & 37.38 & $\begin{array}{c}4.86 \\
(1216)\end{array}$ & 10.39 & $\begin{array}{c}-2.12 \\
(-529)\end{array}$ & 43.49 \\
\hline $\begin{array}{l}\text { Bank's Efforts to know the } \\
\text { customer and his needs }\end{array}$ & $\begin{array}{c}2.93 \\
(733)\end{array}$ & 32.66 & $\begin{array}{c}4.79 \\
(1198)\end{array}$ & 15.83 & $\begin{array}{c}-1.86 \\
(-465)\end{array}$ & 44.46 \\
\hline $\begin{array}{l}\text { Staff's polite approach with } \\
\text { customers }\end{array}$ & $\begin{array}{c}3.43 \\
(857)\end{array}$ & 28.92 & $\begin{array}{c}4.80 \\
(1199)\end{array}$ & 15.77 & $\begin{array}{c}-1.37 \\
(-342)\end{array}$ & 54.75 \\
\hline
\end{tabular}

Source: Computed from primary data

Note: Figures in parentheses indicate the individual factor score

Table 7: Service quality gap of private sector banks in empathy dimension 


\begin{tabular}{|l|l|l|l|l|l|l|}
\hline $\begin{array}{l}\text { Description of Factor } \\
\text { on Financial }\end{array}$ & \multicolumn{2}{|l|}{ Perceived Level } & \multicolumn{2}{l|}{ Desired Level } & \multicolumn{2}{l|}{ Gap } \\
\cline { 2 - 7 } & Score & CV (\%) & Score & CV (\%) & Score & $\begin{array}{l}\text { CV } \\
\text { (\%) }\end{array}$ \\
\hline $\begin{array}{l}\text { Reasonability of the rate of } \\
\text { interest paid }\end{array}$ & $\begin{array}{l}2.86 \\
(716)\end{array}$ & 32.06 & $\begin{array}{l}4.51 \\
(1128)\end{array}$ & 23.10 & $\begin{array}{l}-1.65 \\
(-412)\end{array}$ & 55.52 \\
\hline $\begin{array}{l}\text { Justification of the rate of } \\
\text { interest charged }\end{array}$ & $\begin{array}{l}2.97 \\
(742)\end{array}$ & 37.44 & $\begin{array}{l}4.56 \\
(1141)\end{array}$ & 20.50 & $\begin{array}{l}-1.60 \\
(-399)\end{array}$ & 73.06 \\
\hline Fair draft commission & $\begin{array}{l}2.78 \\
(694)\end{array}$ & 44.39 & $\begin{array}{l}4.32 \\
(1081)\end{array}$ & 31.27 & $\begin{array}{l}-1.55 \\
(-387)\end{array}$ & 79.68 \\
\hline $\begin{array}{l}\text { Affordability of the safety } \\
\text { locker rent }\end{array}$ & $\begin{array}{l}2.75 \\
(688)\end{array}$ & 47.60 & $\begin{array}{l}4.41 \\
(1102)\end{array}$ & 26.28 & $\begin{array}{l}-1.66 \\
(-414)\end{array}$ & 65.06 \\
\hline $\begin{array}{l}\text { Less commission for funds } \\
\text { transfer }\end{array}$ & 2.28 & 43.60 & $\begin{array}{l}4.20 \\
(1050)\end{array}$ & 33.48 & $\begin{array}{l}-1.92 \\
(-481)\end{array}$ & 56.93 \\
\hline $\begin{array}{l}\text { Reasonability of housing } \\
\text { loan rate of interest }\end{array}$ & $\begin{array}{l}2.56 \\
(639)\end{array}$ & 32.42 & $\begin{array}{l}4.51 \\
(1128)\end{array}$ & 17.34 & $\begin{array}{l}-1.96 \\
(-489)\end{array}$ & 50.36 \\
\hline
\end{tabular}

Source: Computed from primary data

Note: Figures in parentheses indicate the individual factor score

Table 8: Service quality gap of private sector banks in financial dimension

interest paid" and "reasonability of housing loan rate of interest $(4.51$ each)". While the average scores of the variables on "affordability of the safety locker rent" and "fair draft commission" were 4.41 and 4.32 respectively. The least value of 4.20 was given to the factor on "less commission for funds transfer". The least coefficient of variation was recorded by the factor on "reasonability of housing loan rate of interest $(17.34 \%) "$

A study on the service quality gap shows that the factor on "fair draft commission (-1.55)" recorded the least. The next lowest gap was registered in the case of "justification of the rate of interest charged $(-1.60)$ ". The third least value was found in the factor on "reasonability of the rate of interest paid" which constituted a score of -1.65 . The highest gap was recorded in the case of variable on the "reasonability of housing loan rate of interest (-1.96)" and the same factor had the least variation of $50.36 \%$.

From the analysis, it can be seen that the variable on the highest service quality gap was being identified in the case of the variable on "reasonability of housing loan rate of interest $(-1.96)$ ", while the same factor had the least coefficient of variation (50.36\%).

\section{Service quality gap of private sector banks in technology di- mension}

The perceived and desired levels of average scores and the resultant service quality gap that arises in the case of technology dimension is discussed vide (Table 9).

Table 9 explains the customers' perceived level of service quality on technology dimension. Among the various factors of technology dimension, the highest score was recorded by the factor "adoption of computers technology to provide service (3.78)". The next highest value was obtained by the factor on "provision of ATM (3.76)". This had been followed by the factor on "provision of e-banking". This variable had taken a value of 3.22. The least value of 2.98 was given to the factor on "provision of core banking". The lowest coefficient of variation was given to the "adoption of computers technology to provide service (27.96\%)".

In the case of desired level, an item wise average score indicated that the highest score was obtained by the factor on "provision of online banking security (5.00)". The next highest score was recorded by the category on the "provision of core banking (4.94)". This is followed by the variable on "provision of mobile banking" which secured a score of 4.93. The variable on "adoption of computers technology to provide service" constituted the lowest average score of 4.74 . The lowest dispersion was recorded in the case of the variable on "provision of online banking security (1.26\%)".

It is seen that among the different variables considered the factor on the "adoption of computers technology to provide service" had the least gap of -0.96 . The next lowest gap was recorded in the case of the variable on "provision of ATM (-0.99)". This was being followed by the variable on "provision of e-banking (-1.64)". The factor on "provision of core banking" had the highest service quality gap of -1.96 and in terms of coefficient of variance the same factor had recorded the lowest variation of $68.73 \%$.

This analysis showed that the factor on "provision of core banking" formed the highest service quality gap indicating that for this factor, difference between the perceived and desired levels was the highest.

\section{Service quality gap of private sector banks in agency dimension}

Table 10 examines the perceived and desired levels of average scores and the resultant service quality gap that arises in the case of agency dimension.

The table points out that the highest score was taken up by the individual factor on "purchase and sales of securities" with a highest value of 3.36. This was followed by the variable on the "payments and

\begin{tabular}{|l|c|c|c|c|c|c|}
\hline Description of Factor & \multicolumn{2}{|c|}{ Perceived Level } & \multicolumn{2}{|c|}{ Desired Level } & \multicolumn{2}{|c|}{ Gap } \\
\cline { 2 - 8 } on Technology & Score & CV (\%) & Score & CV (\%) & Score & CV (\%) \\
\hline $\begin{array}{l}\text { Adoption of computers } \\
\text { technology to provide } \\
\text { service }\end{array}$ & $\begin{array}{c}3.78 \\
(946)\end{array}$ & 27.96 & $\begin{array}{c}4.74 \\
(1185)\end{array}$ & 12.11 & $\begin{array}{c}-0.96 \\
(-239)\end{array}$ & 104.90 \\
\hline Provision of ATM & $\begin{array}{c}3.76 \\
(939)\end{array}$ & 36.78 & $\begin{array}{c}4.75 \\
(1187)\end{array}$ & 11.87 & $\begin{array}{c}-0.99 \\
(-248)\end{array}$ & 127.07 \\
\hline Provision of e-banking & $\begin{array}{c}3.22 \\
(806)\end{array}$ & 47.95 & $\begin{array}{c}4.87 \\
(1217)\end{array}$ & 10.14 & $\begin{array}{c}-1.64 \\
(-411)\end{array}$ & 87.38 \\
\hline Provision of core banking & $\begin{array}{c}2.98 \\
(744)\end{array}$ & 44.40 & $\begin{array}{c}4.94 \\
(1234)\end{array}$ & 4.96 & $\begin{array}{c}-1.96 \\
(-490)\end{array}$ & 68.73 \\
\hline $\begin{array}{l}\text { Provision of mobile } \\
\text { banking }\end{array}$ & $\begin{array}{c}3.14 \\
(785)\end{array}$ & 49.78 & $\begin{array}{c}4.93 \\
(1233)\end{array}$ & 5.11 & $\begin{array}{c}-1.79 \\
(-448)\end{array}$ & 88.10 \\
\hline $\begin{array}{l}\text { Provision of online } \\
\text { banking security }\end{array}$ & $\begin{array}{c}3.10 \\
(776)\end{array}$ & 49.45 & $\begin{array}{c}5.00 \\
(1249)\end{array}$ & 1.26 & $\begin{array}{c}-1.89 \\
(-473)\end{array}$ & 81.16 \\
\hline
\end{tabular}

Source: Computed from primary data

Note: Figures in parentheses indicate the individual factor score

Table 9: Service quality gap of private sector banks in technology dimension

\begin{tabular}{|c|c|c|c|c|c|c|}
\hline \multirow{2}{*}{$\begin{array}{l}\text { Description of Factor } \\
\text { on Agency }\end{array}$} & \multicolumn{2}{|c|}{ Perceived Level } & \multicolumn{2}{|c|}{ Desired Level } & \multicolumn{2}{|c|}{ Gap } \\
\hline & Score & CV (\%) & Score & CV (\%) & Score & $\begin{array}{l}\text { CV } \\
(\%)\end{array}$ \\
\hline $\begin{array}{l}\text { Payments and collection of } \\
\text { subscriptions, dividends, } \\
\text { salaries, pensions, etc., }\end{array}$ & $\begin{array}{l}3.20 \\
(800)\end{array}$ & 34.06 & $\begin{array}{c}4.76 \\
(1190)\end{array}$ & 9.18 & $\begin{array}{l}-1.56 \\
(-390)\end{array}$ & 66.73 \\
\hline $\begin{array}{l}\text { Purchase and sales of } \\
\text { securities }\end{array}$ & & 28.81 & $\begin{array}{c}4.73 \\
(1182)\end{array}$ & 12.69 & & 65.18 \\
\hline $\begin{array}{l}\text { Acting as executor, } \\
\text { administrator \& trustee }\end{array}$ & $\begin{array}{l}3.00 \\
(749)\end{array}$ & 26.63 & $\begin{array}{c}4.73 \\
(1182)\end{array}$ & 12.35 & $\begin{array}{l}-1.74 \\
(-434)\end{array}$ & 48.39 \\
\hline Acting as attorney & $\begin{array}{l}3.06 \\
(765)\end{array}$ & 38.43 & $\begin{array}{c}4.70 \\
(1175)\end{array}$ & 12.68 & $\begin{array}{l}-1.64 \\
(-410)\end{array}$ & 68.23 \\
\hline Acting as cash exchanger & $\begin{array}{l}2.94 \\
(736)\end{array}$ & 37.28 & $\begin{array}{c}4.64 \\
(1160)\end{array}$ & 17.05 & $\begin{array}{l}-1.70 \\
(-424)\end{array}$ & 63.35 \\
\hline $\begin{array}{l}\text { Acting as financial planner, } \\
\text { investment advisors and } \\
\text { brokers }\end{array}$ & $\begin{array}{l}3.14 \\
(786)\end{array}$ & 35.22 & $\begin{array}{c}4.60 \\
(1151)\end{array}$ & 18.26 & $\begin{array}{l}-1.46 \\
(-365)\end{array}$ & 64.38 \\
\hline
\end{tabular}

Source: Computed from primary data

Note: Figures in parentheses indicate the individual factor score

Table 10: Service quality gap of private sector banks in agency dimension 
collection of subscriptions, dividends, salaries, pensions, etc., (3.20)". The third highest average score had been given to the aspect on "acting as financial planner, investment advisors and brokers (3.14)". The lowest value of 2.94 was taken by the variable on "acting as cash exchanger". In terms of the measure of the dispersion, the lowest value of $26.63 \%$ was recorded by the individual variable on "acting as executor, administrator and trustee".

The average score on "payments and collection of subscriptions, dividends, salaries, pensions, etc.," constituted the highest one with 4.76. This variable had recorded the lowest coefficient of variation $(9.18 \%)$. The second highest mean score was registered by the two factors, "purchase and sales of securities" and "acting as executor, administrator and trustee (4.73 each)". This was being followed by the factor on "acting as attorney (4.70)" which formed the third highest average score. The factor on "acting as financial planner, investment advisors and brokers" had recorded the least average score of 4.60 .

Of the six individual factors of service quality gap, the factor on "acting as executor, administrator and trustee" constituted the highest with -1.74. This variable had recorded the lowest coefficient of variation (48.39). The second highest mean score was registered by the factor on "acting as cash exchanger (1.70)". The variable on acting as attorney $(-1.64)$, payments and collection of subscriptions, dividends, salaries, pensions, etc., came next with -1.56 and financial planner, investment advisor and broker followed with -1.46 . The lowest score of -1.37 was recorded in the case of the factor on "purchase and sales of securities".

From the analysis it can be understood that the factor on "acting as executor, administrator and trustee $(-1.74)$ " had recorded the highest score and the variable on "acting as attorney" had registered the highest variation of $68.23 \%$.

\section{Service quality gap of private sector banks in miscellaneous dimension}

The perceived and desired levels of average scores and the resultant service quality gap that arises in the case of miscellaneous dimension is presented in Table 11.

The highest score of 10 was registered by the variable on the "letter of credit". The next highest mean score had gone to the variable on "safe custody of valuables (3.35)". This was followed by the variable on travellar's cheques (3.11), factoring (2.79) and dealing in foreign exchange business (2.73). The lowest value was scored by "leasing finance (2.67)". The lowest value of coefficient variation was registered by "letter of credit (31.88\%)".

\begin{tabular}{|l|c|c|c|c|c|c|}
\hline Description of Factor & \multicolumn{2}{|c|}{ Perceived Level } & \multicolumn{2}{|c|}{ Desired Level } & \multicolumn{2}{|c|}{ Gap } \\
\cline { 2 - 8 } on Miscellaneous & Score & CV (\%) & Score & CV (\%) & Score & CV (\%) \\
\hline $\begin{array}{l}\text { Safe custody of } \\
\text { valuables }\end{array}$ & $\begin{array}{c}3.35 \\
(838)\end{array}$ & 32.60 & $\begin{array}{c}4.81 \\
(1202)\end{array}$ & 15.30 & $\begin{array}{c}-1.46 \\
(-364)\end{array}$ & 62.33 \\
\hline Letter of credit & $\begin{array}{c}3.36 \\
(840)\end{array}$ & 31.88 & $\begin{array}{c}4.86 \\
(1215)\end{array}$ & 10.43 & $\begin{array}{c}-1.50 \\
(-375)\end{array}$ & 59.20 \\
\hline Traveller's cheques & $\begin{array}{c}3.11 \\
(778)\end{array}$ & 40.71 & $\begin{array}{c}4.86 \\
(1214)\end{array}$ & 10.66 & $\begin{array}{c}-1.74 \\
(-436)\end{array}$ & 65.29 \\
\hline Dealing in foreign & $\begin{array}{l}2.73 \\
\text { exchange business }\end{array}$ & 40.81 & $\begin{array}{c}4.92 \\
(1231)\end{array}$ & 5.69 & $\begin{array}{c}-2.19 \\
(-548)\end{array}$ & 50.18 \\
\hline Leasing finance & $\begin{array}{c}2.67 \\
(667)\end{array}$ & 47.57 & $\begin{array}{c}4.89 \\
(1222)\end{array}$ & 6.95 & $\begin{array}{c}-2.22 \\
(-555)\end{array}$ & 56.31 \\
\hline Factoring & $\begin{array}{c}2.79 \\
(697)\end{array}$ & 45.77 & $\begin{array}{c}4.86 \\
(1214)\end{array}$ & 10.66 & $\begin{array}{c}-2.07 \\
(-517)\end{array}$ & 57.44 \\
\hline
\end{tabular}

Source: Computed from primary data

Note: Figures in parentheses indicate the individual factor score

Table 11: Service quality gap of private sector banks in miscellaneous dimension
The factor on "dealing in foreign exchange business (4.92)" had the highest average score. This was followed by the factor on the "leasing finance (4.89)" which had the second highest average score. The third highest score was found in the case of three variables namely, the variable on "factoring", "letter of credit" and "traveller's cheques" which constituted an equal score of 4.86 . The factor on "safe custody of valuables" constituted the least average score of 4.81. In terms of the coefficient of variation, the lowest dispersion was recorded in the case of "dealing in foreign exchange business (5.69\%)".

Among the six broad categories of individual factor that determines the dimension on miscellaneous aspects, the average score of -2.22 was found in the case of the variable on "leasing finance" which constituted the highest gap. The next highest value was found in the case of the variable on "dealing in foreign exchange business". This variable had recorded an average score of -2.19 . The next values were in the order of factoring $(-2.07)$, traveller's cheques $(-1.74)$ and letter of credit (-1.50). The lowest gap was found in the factor on "safe custody of valuables (-1.46)". In terms of coefficient of variation the lowest variation was recorded in the case of "dealing in foreign exchange business" with 50.18\%.

From the analysis it is seen that the factor on "leasing finance $(-2.22)$ " constituted the highest average score, while in terms of coefficient of variation, the "dealing in foreign exchange business (50.18)" formed the lowest dispersion.

\section{Summary and Conclusion}

On the dimension on tangibility the factor on "availability of bank stationery", on reliability the factor on "prompt services", on responsiveness the factor on "rendering of services when approached" and in terms of assurance, the factor on "staff"s skill in computer technology" had recorded the lowest gaps. In terms of accessibility the factor on "proximity of the bank location", in terms of empathy the factor on "staff's polite approach with customers", on financial the factor on "Fair draft commission", on technology the factor on "adoption of computers technology to provide service", on agency the factor on "purchase and sales of securities" and in terms of miscellaneous the factor on "safe custody of valuables" recorded the lowest gaps.

\section{Suggestions}

The private sector banks should raise the quality of the financial services like the reasonability of the rate of interest paid for deposits, justification of the rate of interest charged on loans, fair commission on draft, affordability of the safety locker rent, less commission for funds transfer and reasonability of interest on housing loans.

\section{References}

1. Ananth A, Ramesh R, Prabaharan B (2011) Service Quality Gap Analysis in Private Sector Banks - A Customer Perspective. Indian Journal of Commerce and Management Studies 2: 245-252.

2. Anderson EW, Fornell C, Sehman DR (1994) Customer Satisfaction, Market Share, and Profitability. Journal of Marketing 58: 53-66.

3. Bilal A, Rehman ZU, Jaweria AQ, Asad S (2010) Determinants of Customer Loyalty in the Banking Sector: The Case of Pakistan. African-Journal of Business Management. 